\title{
Correction to: Jaw Metastasis from a Prostate Adenocarcinoma Associated with Numb Chin Syndrome: Case Report
}

\author{
Nara lelo ${ }^{1}\left(\right.$ Mariel Biancardi $^{2} \cdot$ Felipe Trevisan $^{3} \cdot$ Cezar Coimbra $^{3} \cdot$ Carlos Zelandi-Filho $^{4}$. \\ Paulo Sérgio da Silva Santos ${ }^{2}$
}

Published online: 21 September 2021

(c) Springer Nature Switzerland AG 2021

\section{Correction to: SN Comprehensive Clinical Medicine (2021) 3:1042-1046 https://doi.org/10.1007/s42399-020-00720-3}

The article Jaw Metastasis from a Prostate Adenocarcinoma Associated with Numb Chin Syndrome: Case Report, written by Nara Ielo, Mariel Biancardi, Felipe Trevisan, Cezar Coimbra, Carlos Zelandi-Filho and Paulo Sérgio da Silva Santos, was originally published online on 10 February 2021 with Open Access under a "Creative Commons Attribution (CC BY) licence 4.0".

After publication in volume 3, issue 4, page 1042-1046, the author(s) decided to cancel the Open Access. Therefore, the copyright of the article has been changed on 19 August 2021 to (C) The Author(s), under exclusive licence to Springer Nature Switzerland AG 2021 with all rights reserved.

Publisher's Note Springer Nature remains neutral with regard to jurisdictional claims in published maps and institutional affiliations.

The original article can be found online at https://doi.org/10.1007/ s42399-020-00720-3.

Nara Ielo

naraielo@hotmail.com

1 Prudent Assistance Dentistry, Pres. Prudente, SP, Brazil

2 Bauru School of Dentistry, University of São Paulo, Bauru, SP, Brazil

3 Onco Care - Oncology and Radiotherapy Center, Pres. Prudente, SP, Brazil

4 Laboratory Pathological Anatomy and Cytopathology, Pres. Prudente, SP, Brazil 